\title{
Intratubular Large Cell Hyalinizing Sertoli Cell Neoplasia
}

National Cancer Institute

\section{Source}

National Cancer Institute. Intratubular Large Cell Hyalinizing Sertoli Cell Neoplasia. NCI

Thesaurus. Code C162466.

A clinically benign intratubular neoplastic proliferation of large Sertoli cells in the testis. It is associated with prominent basement membrane deposits. It occurs almost exclusively in patients with Peutz-Jeghers syndrome. 